\title{
Comparative Study of the Attack Magnesium Sulphate on Different Types of Portland Cement
}

\author{
Mazer W*, Oliveira MS, Gelinski RMN, Guzzo G, Teixeira M and Oliveira PL \\ Department of Civil Engineering, Federal University of Technology, Brazil
}

Submission: June 19, 2018; Published: July 18, 2018

*Corresponding author: Mazer W, Department of Civil Engineering, Federal University of Technology - Paraná, Brazil, Email: wmazer@utfpr.edu.br

\section{Introduction}

Sulphate attack is one of the major threats to the durability of cementitious materials [1]. It comprises a series of chemical reactions between the sulfate ions and the hardened cement paste, culminating in the formation of secondary ettringite, causing the increase in the volume inside the concrete, the formation of micro-cracks and the erosion of the concrete surface [2,3]. The most common sulfates involved in the deterioration of concrete structures are calcium sulfate $\left(\mathrm{CaSO}_{4}\right)$, sodium sulfate $\left(\mathrm{Na}_{2} \mathrm{SO}_{4}\right)$ and magnesium sulfate $\left(\mathrm{MgSO}_{4}\right)$ [4].

Santhanan et al.[5] present a good review on the attack of sulphates on cementitious materials involving the attack mechanism, tests and modeling parameters. A study on the durability of sulfate-exposed concretes was held by Rozière et al [6]. Brown \& Doerr [7] studied the action of carbonation, the ingress of chlorides and the action of calcium, sodium and magnesium sulphates. Uddin \& Quayyum [8] studied the action of calcium sulphate on mortars. The attack of cement mortars by sodium and magnesium sulphates was studied by Santhanan et al.[5,9] assessing different concentrations and temperatures.

The mechanisms of diffusion and migration of sodium and magnesium sulfates were studied by Lorente et al.[1]. Ouyang et al. [3] assessing the changes in surface hardness of concrete submitted to sulfate attack and verified the influence of water/

Table 1: Chemical composition of the cements.

\begin{tabular}{|c|c|c|c|c|c|c|c|}
\hline Cimento & $\mathbf{S O}_{3}$ & $\mathbf{S i O}_{2}$ & $\mathbf{A l 2 O}_{3}$ & $\mathbf{F e}_{2} \mathbf{O}_{3}$ & $\mathbf{C a O}$ & MgO & P. Fogo \\
\hline CP II F-32 & $2,78 \%$ & $18,46 \%$ & $4,17 \%$ & $2,93 \%$ & $60,60 \%$ & $3,78 \%$ & $4,85 \%$ \\
\hline CP IV -32 RS & $2,27 \%$ & $29,37 \%$ & $9,69 \%$ & $3,95 \%$ & $45,75 \%$ & $2,80 \%$ & $3,56 \%$ \\
\hline CP IV -ARI & $3,14 \%$ & $18,80 \%$ & $4,22 \%$ & $2,95 \%$ & $60,27 \%$ & $3,91 \%$ & $3,33 \%$ \\
\hline CP B & $3,09 \%$ & $17,95 \%$ & $2,98 \%$ & $0,21 \%$ & $59,40 \%$ & $2,87 \%$ & $11,60 \%$ \\
\hline
\end{tabular}

Source: Itambé, 2018 cement ratio and ion concentration. The influence of the cement type on the sulfate attack for the formation of taumasite was studied by Nobst \& Stark [10] who verified the influence of C3A and the amount of $\mathrm{Al}_{2} \mathrm{O}_{3}$.

Magnesium sulphate is considered the most harmful and was used as the object of this study, since it can react with all the hydration products of the cement, forming ettringite and brucite (Mg2SO4)[11]. This last precipitates and causes a decrease in the $\mathrm{pH}$ of the pore solution, leading to the decalcification of the C-S-H phase, which is responsible for the cement cohesion.

Considering the influence of the cement type and the water/ cement ratio on the penetration of sulfate ions in the concrete, the present study evaluated 4 differents Brazilian cements and two water/cement ratios in test speciments submitted to magnesium sulphate[12].

\section{Experimental Research}

For the study were molded cylindrical specimens of mortar with $5 \mathrm{~cm} \times 10 \mathrm{~cm}$, according to NBR 5738/2015, using the Brazilian Portland cement CP II-32 F, CP IV-32 RS, CP V (ARI) and CP B (White), whose chemical compositions are presented in Table 1. The natural sand with fineness modulus 2.45 was used for the molding of the specimens[13]. The mortar was produced with a 1: 3 composition in two water/cement ratios $(\mathrm{w} / \mathrm{c})$ of 0.40 and 0.70 . 
The specimens were healed for 7 days and then submitted to the attack process of magnesium sulphate in $10 \%$ of mass, strength aqueous solution for a period of 11 weeks. The sulfate content in each sample was then determined according to ASTM C 114-07 Standard Test Method for Chemical Analysis of Hydraulic Cement[14].

The results are presented in Figure 1 and indicate the influence of the type of cement and the water/cement ratio on the penetration of magnesium sulphate[15,16].

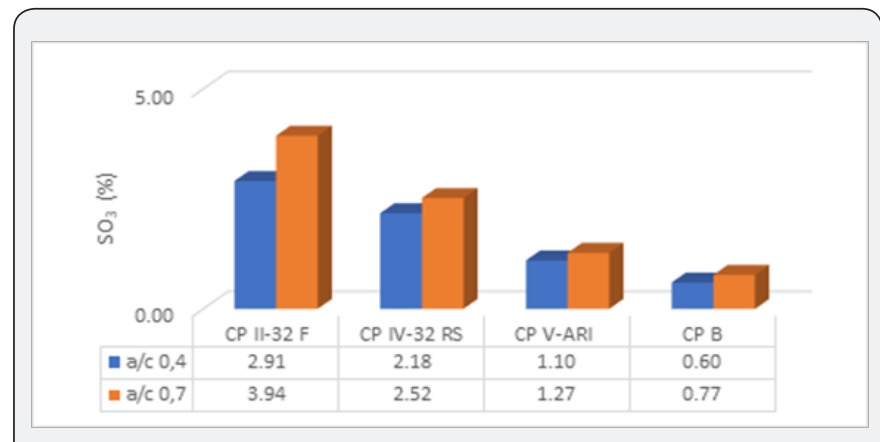

Figure 1: $\mathrm{SO}_{3}$ penetration for each cement tested. Source: authors, 2018

In all cases, it was verified that the increase of the water/ cement ratio leads to a higher sulphate penetration due to the increased permeability of the concrete. As for the influence of the cement type, it was verified that the CP IV and CP V-ARI cements had lower sulphate amounts than the CP II F-32, showing their characteristic of resistance to sulphates when compared to a cement in common use. This characteristic occurs due to the low C3A content in these cements, the fineness of these cements, whose specific surfaces are $4290 \mathrm{~m}^{2} / \mathrm{kg}$ and $4078 \mathrm{~m}^{2} / \mathrm{kg}$, and the additions of pozzolan and filer that make them less pores can still be considered. The white cement (CP B) showed the lowest penetration of sulphates, presenting a feature of resistance to sulfates, keeping with its low C3A content.

\section{References}

1. Lorente S, Yssorche-Cubaynes M, Auger J (2011) Sulfate transfer through concrete: Migration and diffusion results. Cement and Concrete Composites 33(7): 735-741.

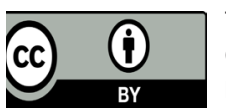

This work is licensed under Creative Commons Attribution 4.0 License DOI: 10.19080/TTSR.2018.02.555593
2. Cefis N, Comi C (2017) Chemo-mechanical modelling of the external sulfate attack in concrete. Cement and Concrete Research, Milano, Italy 93: $57-70$.

3. Ouyang W, Chen J, Jiang M (2014) Evolution of surface hardness of concrete under sulfate attack. Construction and Building Materials 53: 419-424.

4. Skalny J, Marchand J, Odler I (2003) Sulfate attack on concrete. Spon Press, London, UK.

5. Santhanam M, Cohen MD, Olek J (2001) Sulfate attack research - whither now? Cement and Concrete Research 31: 845-851.

6. Rozière E, Loukili A, El hachem R, Grondin F (2009) Durability of concrete exposed to leaching and external sulphate attacks. Cement and Concrete Research 39(12): 1188-1198.

7. Browm PW, Doerr A (2000) Chemical changes in concrete due to the ingress of aggressive species. Cement and Concrete Research 30: 411418.

8. Uddin JMd, Quayyum Md (2012) Influence of Calcium Sulphate on Cement Motor and Characteristics Behaviour at Different Proportions. International Journal of Computational Engineering Research 2(6): 192.

9. Santhanam M, Cohen MD, Olek J (2002) Mechanism of sulfate attack: A fresh look Part 1: Summary of experimental results. Cement and Concrete Research 32(6): 915-921.

10. Nobst P, Stark J (2003) Investigations on the influence of cement type on thaumasite formation. Cement \& Concrete Composites 25(8): 899-906.

11. Liu Z, Deng D, De Schutter G, Yu Z (2013) The effect of MgSO4 on thaumasite formation. Cement and Concrete Composites 35(1): 102108.

12. (2003) American Society for Testing and Materials. A. C 114-03, Standard Test Method for Chemical Analysis of Hydraulic Cement. Philadelphia.

13. (2015) Associação Brasileira De Normas Técnicas. NBR 5738/2015: Concreto - Procedimento para moldagem e cura de corpos de prova. Rio de Janeiro.

14. Itambe. Relatórios de Ensaio (2018) Disponível em.

15. Piasta W, Marczewska J, Jaworska M (2014) Some aspects and mechanisms of sulfate attack. Structure and Environment 6: 3th ed. Kielce, 19-24.

16. Santhanam M, Cohen MD, Olek J (2003) Mechanism of sulfate attack: A fresh look Part 2: Summary of experimental results. Cement and Concrete Research 33: 341-346. 